\title{
COMPARATIVE CHARACTERISTICS OF FREQUENCY ENT PATHOLOGY SCHOOL-AGE CHILDREN
}

Z.I.Tuksanova, F.X.Umarov

BukhSMI, Bukhara, Uzbekistan

Keywords: children of school, chronic tonsillitis, chronic otitis, hygiene, laryngitis, pharyngitis

Abstract: by the received results it is revealed as in the city and in the village among children of school students chronic tonsillitis meets very often. Pathology of decrease in hearing among school students of the city- on the second place, and among school students of the village- on the third place. It is perhaps connected with high medical care of the population in the city. Chronic otitis among children of school-age in city conditions meets on the third place, and in the conditions of the village on the second place. It is explained not by full compliance with hygienic conditions of school students of rural areas. And on incidence to chronic laryngitis and pharyngitis in a residence of distinctions aren't revealed

Relevance: In Uzbekistan, the problems associated with protecting the health of the younger generation, its physical, mental and cultural development, become especially important from year to year.

One of the important tasks in this area is the study of the health of children of school age, the analysis of the prevalence of diseases and the development of measures to reduce them. To plan and implement measures to prevent otorhinolaryngological pathology, improve medical care for patients, it is necessary to have information on the prevalence of ear, nose and throat diseases, as well as on the degree and nature of the influence of various medical and social factors on the formation and maintenance of this pathology in children. In assessing the health of the population, disease incidence play a large role. Studying morbidity only in terms of negotiability does not reflect the real picture, since negotiability depends on the availability of medical care, health literacy, medical activity of the population and other factors.

Objective: to study the characteristics of otorhinolaryngological pathology in children of school age in the conditions of the city of Bukhara and the Bukhara region and to develop organizational and therapeutic measures aimed at reducing the risk of acute and progression of chronic diseases of ENT organs in schoolchildren

Materials and methods: ENT pathology were examined among children of Bukhara and Bukhara region by carrying out preventive examinations. The number of pupils involved medical examination: school students in the city of Bukhara-51 024, pupils in rural schools-92447. Classification of diseases: according to the ICD revision 10

Results and discussion: According to the results of health examination for school-age children found that the overall incidence of ENT pathology was $163.4 \pm 0.9 \%$, including in the context of the city, the figure was $83 \pm 1.2 \%$ and in the context of the village $207 \pm 2.9 \%$ (chart 1 )

Chart 1.Morbidity rate ENT pathology among school-children the Bukhara

\begin{tabular}{|l|l|l|l|}
\hline sickness & city & village & total \\
\hline
\end{tabular}




\begin{tabular}{|l|l|l|l|l|l|l|}
\hline & Abs. & $\%$ & Abs. & $\%$ & abs & $\%$ \\
\hline Chronic laryngitis & 10 & $2.36 \pm 0.7$ & 98 & $5.1 \pm 0.5$ & 108 & $4.6 \pm 0.4$ \\
\hline Chronic otitis & 13 & $3.07 \pm 0.8$ & 1354 & $70.5 \pm 1.8$ & 1367 & $58.3 \pm 1.5$ \\
\hline Chronic tonsillitis & 2035 & $480.5 \pm 7.6$ & 8683 & $\begin{array}{l}451.9 \pm 3 . \\
5\end{array}$ & 10718 & $457.1 \pm 3.2$ \\
\hline $\begin{array}{l}\text { Chronic } \\
\text { pharyngitis }\end{array}$ & 4 & $0.94 \pm 0.4$ & 75 & $3.9 \pm 0.4$ & 79 & $3.4 \pm 0.3$ \\
\hline $\begin{array}{l}\text { Hearing } \\
\text { impairment }\end{array}$ & 138 & $32.6 \pm 2.7$ & 322 & $16.75 \pm 0$. & 460 & $19.6 \pm 0.9$ \\
\hline Total & 4235 & $83 \pm 1.2$ & 19215 & $207 \pm 2.9$ & 23450 & $163.4 \pm 0.9$ \\
\hline
\end{tabular}

According to the results of the study it was found that on the morbidity of ENT organs at the first worth chronic tonsillitis $(457,1 \pm 3.2 \%)$, in a second chronic otitis $(58.3 \pm$ $1.5 \%)$, and the third is a hearing impairment $(19.6 \pm 0.9 \%)$, the fourth is a chronic laryngitis $(4.6 \pm 0.4 \%)$ and in fifth place - chronic pharyngitis $(3.4 \pm 0.3 \%)$.

Children of school-age living in urban settings, first encountered chronic tonsillitis $(480.5 \pm 7.6 \%)$, the second-hearing impairment $(32.6 \pm 2.7 \%)$, the third- chronic otitis $(30,7 \pm 2.7 \%)$, at the fourth chronic laryngitis $-(2,36 \pm 0,7 \%)$ and fifth- chronic pharyngitis- $(0,94 \pm 0,4 \%)$. And children of school-age living in villages, first encountered chronic tonsillitis (451.9 $\pm 3,5 \%)$, the second- chronic otitis $(70,5$ $\pm 1,8 \%$ ), the third- hearing impairment $(17,75 \pm 0,9 \%)$, at the fourth chronic laryngitis $(5,1 \pm 0,5 \%)$ and fifth- chronic pharyngitis- $(3,9 \pm 0,4 \%)$. Thus, according to the obtained results, it was revealed that in the city and in the countryside chronic tonsillitis is found very often among schoolchildren. Pathology of hearing loss among schoolchildren in the city is in second place, and among schoolchildren in the village is in third place. This may be due to the high level of medical care in the city.

Chronic otitis among school-age children in urban settings is in third place, and in terms of the village in second place. This is due to the incomplete observance of hygienic conditions by children of schoolchildren in rural areas. There were no differences in the incidence of chronic laryngitis and pharyngitis at the place of residence.

To compare the morbidity among children of school age, we give the total morbidity (Chart 2.) of this contingent. According to the study, it turns out that the 
overall morbidity of school-age children prevails among schoolchildren living in rural areas $(11586(1254.6 \pm 2.5))$ than in such a cohort in the city $(50516(990 \pm 0.4))$.

Chart 2. Morbidity rates by grade.

\begin{tabular}{|l|l|l|l|l|l|l|l|}
\hline \multirow{2}{*}{ № } & morbidity & \multicolumn{2}{l|}{ city } & \multicolumn{2}{l|}{ village } & \multicolumn{2}{l|}{ common } \\
\cline { 3 - 8 } & abs. & $\%$ & abs. & $\%$ & abs. & $\%$ \\
\hline 1 & $\begin{array}{l}\text { Diseases of the } \\
\text { cardiovascular } \\
\text { system }\end{array}$ & 501 & $9.81 \pm 0.4$ & 1021 & $20.0 \pm 0.6$ & 1522 & $29.81 \pm 0.7$ \\
\hline 2 & $\begin{array}{l}\text { Respiratory } \\
\text { diseases }\end{array}$ & 2255 & $44.19 \pm 0.9$ & 10008 & $196.14 \pm 1.7$ & 12263 & $240.33 \pm 1.8$ \\
\hline 3 & $\begin{array}{l}\text { Diseases of the } \\
\text { digestive } \\
\text { system }\end{array}$ & 16743 & $325.4 \pm 2.0$ & 26897 & $527.05 \pm 2.2$ & 43658 & $855.59 \pm 1.5$ \\
\hline 4 & $\begin{array}{l}\text { Diseases of the } \\
\text { blood and } \\
\text { hematopoietic } \\
\text { system }\end{array}$ & 20577 & $403.28 \pm 2$. & 53571 & $104.99 \pm 1.3$ & 74148 & $508.27 \pm 1.2$ \\
\hline 5 & $\begin{array}{l}\text { Skin and } \\
\text { Venereal } \\
\text { Diseases }\end{array}$ & 188 & $3.68 \pm 0.2$ & 499 & $9.77 \pm 0.4$ & 687 & $13.45 \pm 0.5$ \\
\hline 6 & $\begin{array}{l}\text { Endocrine and } \\
\text { nutritional } \\
\text { disorders }\end{array}$ & 4821 & $94.48 \pm 1.3$ & 15890 & $311.42 \pm 2.0$ & 20711 & $125.62 \pm 1.4$ \\
\hline 7 & $\begin{array}{l}\text { Diseases of the } \\
\text { urinary- } \\
\text { excretory } \\
\text { system }\end{array}$ & 123 & $2.4 \pm 0.2$ & 1044 & $20.4 \pm 0.6$ & 1167 & $22.8 \pm 0.6$ \\
\hline 8 & $\begin{array}{l}\text { Infectious and } \\
\text { parasitic } \\
\text { diseases }\end{array}$ & 668 & $13.07 \pm 0.5$ & 2618 & $51.3 \pm 0.9$ & 3286 & $64.4 \pm 1.0$ \\
\hline 9 & $\begin{array}{l}\text { Diseases of the } \\
\text { nervous } \\
\text { system and } \\
\text { sense organs }\end{array}$ & 4077 & $79.90 \pm 1.2$ & 3756 & $73.61 \pm 1.1$ & 7833 & $153.51 \pm 1.5$ \\
\hline 1 & $\begin{array}{l}\text { Other deseases } \\
0\end{array}$ & 545 & $10.6 \pm 0.4$ & 682 & $13.3 \pm 0.5$ & 227 & $23.9 \pm 0.6$ \\
\hline & \begin{tabular}{l} 
Total: \\
\hline
\end{tabular} & 50516 & $990 \pm 0.4$ & 11586 & $1254.6 \pm 2.5$ & 16650 & $1160.5 \pm 1.9$ \\
\hline
\end{tabular}




\section{Findings:}

1. In the conditions of the city and the village, the same, rather high, morbidity rates in children from the ENT organs were revealed.

2. Improving the quality of medical and preventive care, improving health literacy among schoolchildren is required both in the city and in the village.

3. To prevent the morbidity of school-age children, it is necessary to carry out sanitary-educational work among parents, to ensure that children visit periodic medical examinations - which allows them to detect hidden inflammation sites in a timely manner and prevent the consequences of diseases.

4. Eating foods rich in vitamins plays a big role in preventing morbidity among schoolage people.

\section{Literature}

1. Gulomov Z.S. An immunotherapeutic approach to the treatment of chronic purulent rhinosinusitis with the preparation of interleukin $1 p$ (betaleukin): author's abstract of the dissertation of the candidate of medical sciences. SPb., 2002. - 20p.

2. Perevoshikova N.K., Basmanova E.D., Kazanskaya T.V. " Anaferon for children in the program of rehabilitation of children who often have acute respiratory viral infections on the background of pathology of the lymphopharyngeal ring"

3. Rojavskiy L.A. "The state of health and the organization of medical-preventive care for children in the rural region of the north of Russia": dissertation of the candidate of medical sciences - SPb., 1998-19p.

4. Karimov U.A. Comprehensive assessment of morbidity and improvement of medical care for young children in rural areas of Uzbekistan. Abstract of doctoral dissertation. Tashkent.1994- $48 \mathrm{p}$.

5. Karimbayev Sh.D. A comprehensive social-hygienic study of the incidence of longterm and frequently ill children in the first seven years of life and ways to improve their medical care. Abstract of Ph.D. dissertation. Moscow.1991- 24 p.

6. Mamatqulov B. Medical and social aspects of the formation, protection and improvement of the health of children of the first 7 years of life. Abstract of doctoral dissertation. Tashkent.1997- 32 p.

7. Sultanov R.T., Muhammediyarova R.G. Health care in the Republic of Uzbekistan (static collection). Tashkent 1993- $258 \mathrm{p}$.

8. Population health in the Republic of Uzbekistan in 1994-1995 yy. and some results of health care reform. Tashkent 1996- 96 ст.

9. Karimov U.A. The state of school health care and measures to improve them. Health problems of school-age children. Scientific-practical conference of the Republican scientific-practical conference. Tashkent. 2005- 9-16pp. 